\section{Autoantikörper gegen BPI}

W. Stöcker

Euroimmun Medizinische Labordiagnostika AG, Lübeck, Deutschland

Synonym(e) Anti-BPI-Antikörper; Anti-CAP 57; Autoantikörper gegen Bakterizidie/Permeabilität-erhöhendes Protein

Englischer Begriff anti-bactericidal permeability-increasing protein autoantibodies

Definition BPI ist ein kationisches, für gramnegative Bakterien toxisches Membran-assoziiertes Protein.

Molmasse $55 \mathrm{kDa}$.

Untersuchungsmaterial Serum, Plasma.

Probenstabilität Autoantikörper sind bei $+4{ }^{\circ} \mathrm{C}$ bis zu 2 Wochen, bei $-20^{\circ} \mathrm{C}$ über Monate und Jahre hinweg beständig.

Analytik Autoantikörper gegen Granulozytenzytoplasma. Antikörper gegen BPI zeigen in der Immunfluoreszenz ein cANCA-Muster, das manchmal in ein pANCA übergeht. Bei positiven oder fraglichen Immunfluoreszenz-Ergebnissen
( $\triangleright$ Immunfluoreszenz, indirekte) ist zur Absicherung und Differenzierung der Befunde die Druchführung eines $\triangleright$ Enzyme-linked Immunosorbent Assay mit definiertem, aus humanen Granulozyten isoliertem Zielantigen notwendig.

\section{Referenzbereich - Erwachsene Negativ.}

\section{Referenzbereich - Kinder Negativ.}

Indikation Keine, da Autoantikörper gegen BPI bei verschiedenen Erkrankungen vorkommen können und keinen differenzialdiagnostischen Nutzen haben.

Diagnostische Wertigkeit Autoantikörper gegen BPI scheinen generell bei Entzündungsreaktionen gebildet zu werden und weisen keine Krankheitsspezifität auf. Sie wurden u. a. beschrieben bei zystischer Fibrose, ANCA-assoziierten Vaskulitiden, Colitis ulcerosa, Morbus Crohn, Autoimmunhepatitis, primär-sklerosierender Cholangiitis, HIV-Infektionen.

\section{Literatur}

Schultz H, Weiss J, Carroll SF, Gross WL (2001) The endotoxin-binding bactericidal/permeability-increasing protein (BPI): a target antigen of autoantibodies. J Leukoc Biol 69:505-512 